Dauphine Was Right: Masques, the Authenticity of (Un)Performed Identity and the Two

\title{
Prologues of Epicene
}

Epicene has two prologues. As students of Jonson know, two prologues in and of itself is not unusual. Jonson was fond of front matter and often loaded his texts with multiple paratexts, a technique often interpreted as a symptom of his obsessive need to control how his plays were received. ${ }^{1}$ The specific case of Epicene is, however, unusual and poses suggestive interpretive problems. For example, unlike the two prologues of Catline and The Staple of News, which are directed at two sets of readers and playgoers respectively, both of Epicene's prologues address the same audience. Furthermore, they address this single audience in substantially different, even oppositional, terms. The first generously invites the audience to enjoy the play and asserts that all will find something to enjoy. The second bitterly complains that this same audience can't properly interpret the play. The second, of course, seems very Jonsonian, ambivalent about the value of the playhouse and at times downright hostile to playgoers, while the first seems uncharacteristically optimistic about stage performance. ${ }^{2}$ Editors of Jonson have long argued that the second prologue, which the subtitle asserts was “Occasioned by some person's impertinent

\footnotetext{
${ }^{1}$ For one version of this theory see Jonas Barish, Anti-theatrical Prejudice (Berkley: University of California Press, 1981), 138-139. See also Joseph Loewenstein, Ben Jonson and Possessive Authorship (Cambridge: Cambridge University Press, 2002) and George E. Rowe, Jr., "Ben Jonson's Quarrel with Audience and Its Renaissance Context," Studies in Philology 81, no. 4 (1984): 447.

${ }^{2}$ John Gordon Sweeney also points out that the prologue is unusual, but focuses on its connection to popular traditions as opposed to learned traditions, and P.K. Ayers describes the first prologue as "uncharacteristically conciliatory." Sweeney, Jonson and The Psychology of the Public Theater: To Coin the Spirit Spend the Soul (Princeton: Princeton University Press, 1985), 105. Ayers, "Dreams of the City: The Urban and the Urbane in Jonson's Epicoene," Philological Quarterly 66, no.1 (1987): 76.
} 
exception," was almost certainly provoked by Lady Arabella's complaint that the play satirized her. ${ }^{3}$ But if the second prologue was a revision of the first, why retain the first prologue?

This is particularly puzzling because, as Richard Dutton has convincingly argued, the second prologue is probably the only aspect of the play that Jonson changed after the initial performance and before the publication of the folio. ${ }^{4}$ Jonson seems to have been telling the truth, more or less, when he asserted in the dedication to Epicene, "There is not a line or syllable in it changed from the simplicity of the first copy" (8-9). Thus, the optimistic first prologue was "meant" for performance, and the revised, second prologue may reframe or reinterpret the play but doesn't change its actual content. The first prologue appears to be an unincorporated remainder to an otherwise unified and authoritative text, an uncharacteristically casual move for an author who obsessively sought control over his texts. Doubly strange since this oversight exists within the very method (prologues) that he uses to control the reception of his plays.

Rather than viewing the first prologue as an unincorporated remainder, I will argue that the second prologue can be usefully understood as dialectically related to the original prologue, even though it was "occasioned" by an outside force. That is, while the second prologue was written after the first, its tone and content are embedded in the play itself, and the oppositional nature of the two prologues mirrors the oppositional structure of the play. In fact, when the two prologues are put in dialogue with each other and with the play proper and with the play's reception, the total situation of Epicene (its reception, paratexts and playtext) captures Jonson's shifting and complex thoughts on the role of performance and the nature of identity, while uncovering Jonson's momentary flirtation with a very un-Jonsonian pro-theatricality.

\footnotetext{
${ }^{3}$ Ben Jonson, Epicene or The Silent Women, ed. Richard Dutton (Manchester: Manchester University Press, 2003). All subsequent quotations are taken from this edition and cited in text. "Dutton, "Introduction," in Epicene, 72-75. For a dissenting view, see Thomas Kranidas, "Possible Revisions or Additions in Jonson's Epicoene," 83 (1965): 451-453.
} 
This shifting view of theatricality that Epicene narrates and embodies can be summarized as follows. Immediately before writing Epicene, Jonson had a string of successes as the masque writer for James's court. The optimism of the first prologue can be traced to these successes because Jonson's court masques claim for themselves the ability to construct an authentic identity through performance, thus participating in an anti-essentialism and a pro-theatricality that the new historicists argue permeates much of Renaissance drama, but which Jonson generally avoids. As Jonas Barish and Thomas M. Greene long ago demonstrated, Jonson prefers stable and unified characters, a predilection that rejects Renaissance self-fashioning and looks forward to (while influencing) enlightenment essentialism. ${ }^{5}$ But in Epicene, we see Jonson importing a pro-theatricality from court culture to the public stage, hence the optimism of the first prologue. However, Jonson hedges this optimism, making Truewit voice and act out this position in competitive dialogue with Clerimont and Dauphine, who both challenge Truewit's theatricality. Thus, while the play seems to embrace a masque-like acceptance of constructed identity and pro-theatricality, the text contains its own opposite. So when Lady Arabella objected to the first performances, the play was uncannily poised to revert to a typically Jonsonian antitheatricality. The pro-theatricality and anti-essentialism embedded in the first prologue and Truewit's character evaporate once Arabella asserted a foundation to the performance - herself. According to her, the fictive performances are not creating identities independent of a nonperformed reality, they are commenting on her reality and creating simulacrums of herself. This reaction led Jonson to revert to the Horatian stance expressed in the second prologue, which assumes a foundational (and according to Jonson, an anti-theatrical) perspective. But the second prologue was there all along, implicit in Truewit's competition with Dauphine and Clerimont.

5 Barish, 132-135. Thomas M. Greene, "Ben Jonson and the Centered Self," Studies in English Literature, 1500-1900 10, no. 2 (1970): 325-348. 
Put more simply, the tonal tension between the two prologues mirrors the competitive tension between Truewit and Dauphine/Clarimont. And both these tensions embody the conceptual conflicts between court entertainment and public drama, theatricality and anti-theatricality, performativity and essentialism.

\section{Masques on the Public Stage: Adding through Subjection}

In his introduction to Epicene, Richard Dutton speculates that when Jonson "returned to the theater [after three years writing for the court], he carried with him memories of his two most recent entertainments. ${ }^{, 6}$ And in fact there are several links between Epicene and the last masque Jonson wrote before returning to the public stage - Britain's Burse. Three actors and friends of Jonson, Nathan Field, William Ostler and Giles Cary, performed in Britain's Burse and Epicene. ${ }^{7}$ And both performances are set in the Strand. Furthermore, the "rare entertainment" referenced at 1.4.28-29 is probably a reference to Britain's Burse. ${ }^{8}$ There are also several more general references to courtly entertainments sprinkled throughout the play: masques at 2.2.34, Lord Mayor's Pageant at 3.2.60, Lord's Masque at 3.2.69 and a marriage masque at 3.7.89.

Despite the biographical and historical connections between masques and Epicene, this link remains relatively unexplored by critics of Epicene. This is unfortunate because Epicene appears to have been heavily influenced by the anti-essentialism that Jonson explores in his court entertainments, and this influence helps explain the unusual pro-theatricality and generosity of

\footnotetext{
${ }^{6}$ Dutton, 10.

${ }^{7}$ Ian Donaldson, Ben Jonson, A Life (Oxford: Oxford University Press, 2011), 243.

${ }^{8}$ Dutton, 137.
} 
the first prologue. Laura Levin, in one of the few studies that substantially explores the influence of masques on Epicene, comes to the opposite conclusion. For her, "Dauphine's final revelation of Epicoene as a boy involves a masque-like assertion of certainty." 9 She seems to assume that masques are inherently anti-theatrical because they assert a stable reality which lies beneath the performance. Put another way, Jonson assumed that performance adds to and covers up an essential identity, but by revealing itself to be a performance, masques subtract or uncover that essential identity, thus reasserting a stable, unchanging identity that exists underneath the surface of performance.

But this view of masques (which interestingly Barish rejects) seems to assume that Jonson believed in the stability of the court - that there was an essential identity to the court that existed underneath the performance and that could be exposed through masques. ${ }^{10}$ I doubt he did. If he believed in a stable court, he probably wouldn't have attempted to alter that court through his poetry. Donaldson argues that masque writing was "an occupation that satisfied

\footnotetext{
${ }^{9}$ Laura Levine, Men in Women's Clothing: Anti-theatricality and Effeminization, 1579-1642 (Cambridge: Cambridge University Press, 1994), 86. Kate D. Levin also explores the connection between masques and Epicene but is more interested in the dramaturgical problems that this link opens up than the theoretical issues that Levine and my own work explore. And Michael Shapiro notes in passing that in writing Epicene, Jonson was "perhaps drawing on his recent experience as protégé of aristocratic patrons and maker of court masques." Shapiro, "Audience vs Dramatist in Jonson's Epicoene and Other Plays of the Children's Troupes," English Literary Renaissance 3 (1973): 411. Levin, "Unmasquing Epicoene: Jonson's Dramaturgy for the Commercial Theater and Court," in New Perspectives on Ben Jonson (Cranbury, NJ: Associated University Presses, 1997), 128-153. Jannet Dillion glances at the connection between masques and Epicene but focuses on the negotiation between city and court, and like Levine, argues that the play is offering a critique the social performances of London citizens. Dillion, "The Masking of Place", in Theater, Court and City 1595-1610 (Cambridge: Cambridge UP, 2006) 124-135. For broader studies that establish the influence of masques on Jacobean public theater, see John R. Ziegler, "“The Hall must not be pestered": Embedded Masques, Space, and Dramatized Desire," Medieval \& Renaissance Drama in England 26 (2013): 97-119 and Ashley H. Thorndike, "Influence of the Court-Masques on the Drama, 1608-1615," PMLA 15, no. 1 (1900): 114-120.

${ }^{10}$ Barish, 152.
} 
Jonson's deepest instincts concerning the proper role and function of the poet, as guide and counsellor to the monarch." ${ }^{11}$ Influencing the monarch would be difficult if the identity of the monarch was entirely fixed and eternal. In fact, many of his public plays, such as Sejanus and Poetaster, explore the mutability of the court, by detailing courtier manipulation and asserting the poets duty to correct that corruption through his own (more enlightened) manipulation. ${ }^{12}$

In fact, the revelation of the true identity of the performers, which Levine reads as a belief in the stability of identity, is used within masques to alter those identities. As Stephen Orgel and Jonathan Goldberg have shown, the purpose of uncovering the identity of court performers was not to merely show that they have always already been that which they are representing, but to transform the courtiers into what and who they were performing. ${ }^{13}$ Through the performance of the masque, James is encouraged to take on the qualities of Mercury or Neptune; Prince Henry becomes Oberon, the Queen becomes Bel-Anna. As Orgel puts it, "the ultimate goal in the masque form was to merge the two characters [the masquer and the fictive role of the masquer], to create a symbolic figure that would be an adequate representation of the courtier beneath the mask." ${ }^{, 14}$ Masques don't assert a stable reality and an anti-theatricality; rather they manipulate reality through performance. ${ }^{15}$ When masques reveal or subtract the

\footnotetext{
${ }^{11}$ Donaldson, 236.

${ }^{12}$ For a description of Jonson's belief in the public role of his poetry, see William Kolbrener, ""Man to Man": Self-Fashioning in Jonson's "To William Pembroke," Texas Studies in Literature and Language 39, no. 3 (1997): 284-295.

${ }^{13}$ Stephen Orgel, The Power of Illusion: Political Theater in English Renaissance (Berkeley: University of California Press, 1975) and The Jonsonian Masque (New York: Columbia University Press, 1981). Jonathan Goldberg, James I and the Politics of Literature: Jonson, Shakespeare, Donne and Their Contemporaries (Baltimore: John Hopkins University Press, 1983), esp. 55-65.

${ }^{14}$ Orgel, The Jonsonian Masque, 68.

${ }^{15}$ Barish argues that Jonson views masques as a "symbol for what is fleeting, trumped-up, and inauthentic." But as I will show, within Epicene the fleeting becomes authentic. Barish, 142.
} 
performance from the identities of the performers, they are also producing and adding to that performance. They add through subtraction.

As I will be arguing throughout, the first prologue and Truewit's character seems to embrace this view of performance, but I would also like to suggest, in passing, that this masquelike impulse perhaps helps explain the unusual topicality and verisimilitude of the play. ${ }^{16}$ During masques, the object of performance and the subject of performance are identical, so the masque can show the actors/courtiers who they can be through the characters they are playing. They can become the character because they are playing the character. This of course isn't the case on the public stage, where the nominal object of the performance (the audience) is alienated from the subject of performance by the actors and staging. However, Epicene bridges that gap (like Ibsen would do over 250 years later) by showing the audience themselves. Dryden's famous assertion that Jonson was "actually acquainted" with characters like Morose has been challenged by modern critics, but the uncharacteristic realism of the play is largely undisputed. ${ }^{17}$ Indeed, this was the first of Jonson's comedies set entirely in London. P.K. Ayers goes as far to suggest that Epicene is the "first play in the history of English drama to concern itself exclusively with polite society." ${ }^{18}$ These polite characters that Ayers refers to (as opposed to the seedy, underworld characters that normally populate city comedies) came from the same social group as Epicene's first audiences, whom Michael Shapiro describes as "old-line aristocrats struggling to maintain their standing; or gentry, nouveaux riches, and young inns-of-court men striving for higher status." ${ }^{19}$ In short, the characters in the play reflect the audience of the play. Furthermore, the

\footnotetext{
${ }^{16}$ Dutton, 10.

${ }^{17}$ John Dryden, An Essay of Dramatic Poesy, in Essays of John Dryden, ed. W.P. Ker (Oxford: Oxford University Press, 1900), 84.

${ }^{18}$ Ayers, 74.

${ }^{19}$ Shapiro, 401.
} 
play was first produced at Whitefriars just down the road from the Strand, where the play is mainly set. Of course, Jonson could have chosen to produce a Whitefriar's based city comedy for a number of reasons, but one possible reason (and one probable effect) was to break down the distance between the subject of the performance and object of the performance in order to make the play function more like a masque: show the audience different versions of themselves.

Intuitively, this masque-like project couldn't work through traditional satire (Jonson's default mode) since an audience would be offended not delighted to watch themselves mocked. Jonson the masque writer knew this, which is why masques function through flattery and pleasure. At its heart, a masque attempts to do political work by pleasuring the court. Graham Parry calls masques and all court entertainments, "festivals [that] show the court united in pleasure." ${ }^{20}$ More recently Martin Butler has taken issue with the notion that masques portray a unified court and instead highlights the fractured politics that is represented and produced through the performances, but he still insists that masques are part of the "pleasurable 'work' associated with the early modern court" and notes that the "court's pleasures always had some political aspect"21 Butler is building on Orgel's more muscular assertion that masques' "seriousness was indistinguishable from their recreative quality." 22

Likewise, Jonson tries to frame Epicene as a work that will produce almost universal pleasure. Through the common Jonsonian conceit of a banquet, the first prologue declares that plays/meals should appeal to the audiences'/guests' tastes and not the playwright's/chief's.

${ }^{20}$ Graham Parry, "Entertainments at Court," in A New History of Early English Drama, eds. John D. Cox and David Scott Kastan (New York: Columbia University Press, 1997), 195. ${ }^{21}$ Martin Butler, The Stuart Court Masque and Political Culture (Cambridge: Cambridge University Press, 2008), 9,5.

${ }^{22}$ Orgel, The Illusion of Power, 38. See also James Knowles, "'Tied to rules of flattery"'? Court Drama and the Masques," in A Companion to English Renaissance Literature and Culture, ed., Michael Hattaway (Malden, MA: Wiley-Blackwell: 2010), 525-524. 
Our wishes, like to those make public feasts,

Are not to please the cooks' tastes, but the guests'.

Yet if those cunning palates hither come,

They shall find guests' entreaty and good room;

And though all relish not, sure there will be some

That, when they leave their seats, shall make 'em say,

Who wrote that piece could so have wrote a play,

But that he knew this was the better way.

The Poet prays you, then, with better thought

To sit; and when his cates are all in brought,

Though there be none far-fet, there will dear-brought

Be fit for ladies; some for lords, knights, squires,

Some for your waiting-wench and city-wires,

Some for your men and daughters of Whitefriars (8-15;19-24).

This conceit explicitly rejects Asper's assertion in Every Man Out of His Humour (written about nine years earlier) that the play/meal was not prepared/seasoned for every palate/playgoer. ${ }^{23}$ Indeed, Jonson deploys this trope several times throughout his career (The New Inn, Cynthia's Revels, Staple of News, Volpone), but Epicene is the only play that uses the metaphor to create a welcoming, egalitarian mood. Its use in The New Inn is more representative than its deployment in Epicene.

You are welcome, welcome all, to the New Inn.

${ }^{23}$ Here as elsewhere I am relying on Dutton's comprehensive notes from the Revels edition, which trace these intertextual connections. 
Though the old house, we hope our cheer will win

Your acceptation; we ha' the same cook

Still, and the fat, who says you sha' not look

Long for your bill of fare, but every dish

Be served in i'the time and to your wish.

If anything be set to a wrong taste,

'Tis not the meat there, but the mouth's displaced;

Remove but that sick palate, all is well (1-9). ${ }^{24}$

Here if the audience/guests dislike the play/meal, it is the fault of their palates not the playwright's/cook's talent. In fact, Jonson seems to be referencing his earlier uses of this trope by calling himself "the same cook." The Cook's perspective on his audience seems to have remained remarkably consistent throughout his long career, from Every Man out of His Humour in 1605 to The New Inn in 1629. The egalitarian affectation of the play/feast metaphor in Epicene seems an aberration, unique among Jonson's public plays.

But its use is not unique within Jonson's private/public cannon. The only other time that Jonson uses this trope for egalitarian purpose is within his masque, Neptune's Triumph. In a dialogue between the Cook and the Poet, the Cook equates his job to that of the Poet, claiming, I am by my place to know how to please the palates of the guests; so you are to know the palate of the times: study the several tastes, what every nation, the Spaniard, the Dutch,

\footnotetext{
${ }^{24}$ Ben Jonson, The New Inn, in The Cambridge Edition of the Works of Ben Jonson, ed. Julie Sanders (Cambridge: Cambridge University Press, 2012), 6: 189-313.
} 
the French, the Walloon, the Neapolitan, the Briton, the Sicilian can expect from you (27$30) .^{25}$

The Poet eventually agrees with the Cook, declaring him his "brother" (79) and allowing him to write the antimasque. The dialogue that yokes the Cook and the Poet even glances at Epicene. The Cook's child refers to the persons presented in the antimasque as "Epicene"(184). And both the dialogue in the masque and the first prologue to Epicene pun on "relish."

This redeployment of the trope is more, I think, than mere recycling of material. Jonson seemed to have had a long (and sometimes spiteful) memory and often made references to much earlier works, events and people in his texts, perhaps only as a joke/reminder to himself or a small circle of intimates. ${ }^{26}$ In this case, the echo of Epicene within his masque and the glances at masques within Epicene suggest links between a public and a courtly audience. After all, the feast the Cook prepares in Neptune's Triumph is for the court, and the metaphoric banquet in the prologue to Epicene is a "public feast." In fact, in the fourth act of Epicene, Truewit lumps courtly performances, feasts, and public plays together into a category of entertainment befitting the young gallant Dauphine; he encourages him to go to "court, to tiltings, public shows and feasts, to plays" (4.1.58-60). ${ }^{27}$ Here, the courtly audience is conflated with the public audience; Truewit suggests that they are (or should be) the same people. And something similar is happening in the prologue. The court and the public are linked through the egalitarian feast. All

\footnotetext{
${ }^{25}$ Ben Jonson, Neptune's Triumph for the Return of Albion, in The Cambridge Edition of the Works of Ben Jonson, ed. Martin Butler (Cambridge: Cambridge University Press, 2012), 5: 653671. All subsequent quotations are taken from this edition and cited in text.

${ }^{26}$ See for instance Dutton's argument in Ben Jonson, Volpone and the Gunpowder Plot (Cambridge: Cambridge University Press, 2012).

27 Truewit is not being entirely serious and is partially satirizing those who go to these entertainments to "see and to be seen." (4.1.61). As always, Jonson is being fairly even handed with his criticism - mocking everyone in sight. But the important point, for my argument, is that the audiences for these entertainments are conflated.
} 
of the court will find something to please them within Neptune's Triumph just as each playgoer at Whitefriars will find something to please them within Epicene (but not apparently in The New Inn, Cynthia's Revels, Staple of News or Volpone).

Truewit vs Clerimont: Jonsonian Masque's triumph over Jonsonain Drama

Keeping in mind the connections between the pro-theatrical masque form and Epicene adds an additional resonance to Clermont and Truewit's rather conventional debate about the relative values of nature and art. ${ }^{28}$ Clerimont can be understood as putting forth a traditional Jonsonian understanding of performance (performance adds to and covers up an essential identity), while Truewit argues for a masque-like view of performance (revealing while adding to an unstable identity).

Clerimont's famous "Still to Be Neat" song portrays theatricality negatively, as unenjoyably obscuring an authentic self.

Still to be neat, still to be dressed,

As you were going to a feast;

Still to be powdered, still perfumed:

Lady, it is to be presumed,

Though art's hid causes are not found,

All is not sweet, all is not sound.

\footnotetext{
${ }^{28}$ My reading of the play as a series of competitions between the gallants is indebted to George E. Rowe, Distinguishing Jonson: Imitation, Rivalry, and the Direction of a Dramatic Career (Lincoln: University of Nebraska Press, 1988).
} 
Give me a look, give me a face,

That makes simplicity a grace;

Robes loosely flowing, hair as free:

Such sweet neglect more taketh me

Than all th' adulteries of art.

They strike mine eyes, but not my heart (1.1.89-100).

Playing off the prologue's gustatory conceit, lack of theatricality is seen as sweeter, more tasty than performance. Art is "not sweet;" nature is "sweet neglect." Furthermore, nature is seen as the absence of art; authentic identity is the absence of performance. This understanding of performance is the exact opposite lesson one learns from Jonson's masques, which work to uncover and construct an authentic identity through performance.

On the other hand, Truewit (whom Barish and Sweeny suggest Jonson identified with) argues for a masque-like view of performed identity. ${ }^{29} \mathrm{He}$ disagrees with Clerimont, "I am clearly o' the other side"(1.1.101) and argues that art corrects or mends nature: "If she have good ears, show 'em; good hair, lay it out; good legs, wear short clothes; a good hand, discover it often; practice any art to mend breath, cleanse teeth, repair eyebrows, paint, and profess it." (1.1.105-108 emphasis mine). Perfection does not operate in the absence of art but through the presence of art. Art is able to produce a perfection that does not exist in unadorned nature, thus performance is able to produce a woman who is "complete and finished" (1.1.123). The process is similar to the addition through subtraction of masques. The verbs mend, cleanse and repair all subtract - odor, filth, unwanted hair respectively, but they subtract not to uncover a prior perfection but to produce that perfection.

${ }^{29}$ Barish, 153. Sweeney, 110-111. 
And significantly, Truewit asserts that performed identity is more enjoyable than an identity that exists outside of theatricality. Truewit's story of visiting a woman in her chamber before she has adorned herself is portrayed (like Stephon's experience in Swift's poems) as unenjoyable (1.1.124-135). ${ }^{30}$ And in fact Clerimont seems to agree. After Truewit describes the lady's appearance, Clarimont remarks, “Oh, Prodigy (1.1.130). "Prodigy” can be understood as describing Truewit's experience as unusual, but it also suggests an unnatural monster.

Surprisingly, he seems to be admitting that her unprepared and unperformed appearance is unnatural or inauthentic and unenjoyable - the exact opposite of his previous argument. In other words, Clerimont seems unable to counter Truewit's examples.

That is until Truewit himself provides him with a counterexample. After Truewit constructs the connections among performance, authenticity and enjoyment, he becomes frustrated at the way others (particularly Daw and LaFoole) harness the power of social performance. Truewit believes Daw to be "a fellow that pretends only to learning, buys titles, and nothing else of books in him" (1.2.75-77), so when Clerimont maintains that "the world reports him [Daw] to be very learned" and that he heard "very good things come from him" (1.1.78/1.1.80-81), Truewit gets angry and storms off. This scene can be read as an extension of the initial debate between Clerimont and Truewit. Clerimont knows very well that Daw is a ridiculous human being (as soon as Truewit leaves, he and Dauphine mock Daw's courtship of Epicene) but is using Daw as a reducto ad absurdum example to counter Truewit's early argument. While Truewit argued that women's public performance of beauty is more authentic than their private bodies because such a public performance is enjoyable, the case of Daw shows

\footnotetext{
${ }^{30}$ See Jonathan Swift, "Strephon and Chloe" and "The Lady's Dressing Room," in The Poems of Jonathan Swift, ed Harold Williams (Oxford: Oxford University Press, 1958), 2: 524-530;584593.
} 
that a public performance can create a personality that is clearly absurd - Daw as learned gentlemen. Truewit has been hoist on his own petard. He complains about Daw's pretense ("pretends only to learning") but has just argued for the authenticity of pretense, especially pretense that is enjoyed and endorsed by an audience. Since the public seems to enjoy Daw's performance, Truewit cannot deny the authenticity of Daw's (pretended) learning.

Consequently, Truewit is forced to admit the authenticity of Daw's performance of learning. By storming out after Clerimont asserts Daw's identity, Truewit is ceding authority to Clerimont's interpretation of Daw's character. Clerimont's surprised reaction to Truewit's exit “This is very abrupt!”(1.2.85) - can be read and performed as a good natured but sarcastic and snarky jab at his friend. Clerimont knows why Truewit abruptly left, because he goaded him into leaving. Similarly, after the final unmasking of Epicene, Morose silently (for once) leaves the stage. As we will see, he too is forced to recognize and validate his enemies' performed identities.

Because Truewit can't disagree or challenge the authentic construction of identity, he works to construct his own identity of Daw. That is, Truewit doesn't counter Clerimont's counterexample of Daw by offering his own interpretation of Daw's character, which would only negate Daw's performance - show it to be only performance. Instead, Truewit offers another performance. Truewit's trick at 4.5, where Daw and La Foole are fooled into humiliating each other, is essentially a piece of theater produced for the benefit of the Collegiates, so they can revise their opinion of Daw and La Foole, whom they think gallant, and Dauphine, whom they think foolish. Indeed, the trick is set up as a performance; when Truewit approaches Epicene to enlist her help, he asks, "Pray thee perform it, and thou win'st me an idolater to thee everlasting" (4.4.177-178 emphasis mine). Truewit also asks Clerimont and Dauphine to witness the "plot" 
and to be a "chorus behind the arras, and whip out between the acts and speak" (4.5.19/32-33). The result of the performance (like the successful performances of masques) is a construction of identity - Daw and La Foole are kicked out of the "court" of the Collegiates, and Dauphine is let in. But Jonson is careful to note that this transformation is not the result of revealing Daw and La Foole's real character (as readers often assume). ${ }^{31}$ Rather, the performance constructs characteristics in addition to their previous performed identities. When Centaure blames Mavis for recommending the two, Mavis retorts, "I commended but their wits, madam, and their braveries. I never looked towards their valours." (4.6.5-6). They are being kicked out of the college because they have been constructed through the performance as cowards. Their previous performance as well dressed, witty knights remains. The trick was not meant to negate Daw's learning; it was meant to construct his cowardly identity.

Throughout the play, Truewit's tricks rely on the authenticity of performed identity. For instance, dressing Otter and Cutbeard up like a lawyer and a clerk, is framed as a way of exploiting the constructed nature of identity. When Dauphine opines that his ruse will not work, Truewit boldly asserts that all he has to do is “Clap but a civil gown with a welt o' the one, and a canonical cloak with sleeves o' the other, and give 'em a few terms i' their mouths." (4.7.42-44). In other words, all he has to do is write them a script and give them the costume. Playing at priests and lawyers will do more, he seems to be suggesting, then trick Morose into thinking they are what they pretend to be, they will in fact become what they pretend to be. He reassures Dauphine that he is not attempting to hurt "the dignity of either profession, since they are but persons put on, and for mirth's sake" (4.7.47-49). The referent to "they" is, I think, purposely obscured. "They" seems to refer to Otter and Cutbeard, so the line simply reassures Dauphine

${ }^{31}$ For instance, Shapiro calls this a "humiliating exposure," 414. 
that he is merely joking. But "They" could also refer to lawyers and priests. In which case, Truewit is stating what he has been arguing since the beginning of the play: identity is nothing but social performance. Lawyers and priests are constitutive of their clothes and language. They are what they pretend to be especially when it is done "for mirth's sake." Therefore, Truewit isn't hurting their dignity because there is no dignity to hurt. Identity is always a social game.

Truewit vs Dauphine: Jonsonian Drama’s revenge on Jonsonian Masque

Because Truewit's tricks keep working, it seems like his version of performance wins out over Clerimont's. In fact, by act four, Clerimont seems to have become convinced by Truewit's performances: "I think I shall come about to thee again, Truewit" (4.1.33-34). However, there is an asterisk next to Truewit's victory. As Rowe rightfully points out, "having proved his superiority to Clerimont, the man who seemed his only serious rival in the play, Truewit finds his achievements unexpectedly overshadowed by those of Dauphine. ${ }^{, 32}$ Or as Truewit presciently observed earlier in the play, "he that thinks himself the master-wit is [often] the master-fool" (3.6.49-50). By the end of the play, all the performances that construct authentic identity are shown to be operating under a broader performance that hides authentic identity. The reveal at the end of the play is used in Epicene to uncover the true characteristics (and gender) of the title character. Performance is shown, after all, to hide authenticity not construct it. While we thought we were in Truewit's play (that resembles a masque), it turns out we were in Dauphine's all along (which resembles a typical Jonsonian public play). This seems to permanently

${ }^{32}$ Rowe, 122. 
undermine what promised to be a radical revision or reversal of the typical Jonsonian antitheatrical position.

In fact, it doubly confirms that position since, as several critics have noted, Jonson dupes his own audience. ${ }^{33}$ There is no dramatic irony in the final revelation; the audience is not in on the ultimate performance. We, like Morose, are put in the position of feeling stupid for believing Epicene is a woman and for not catching the obscure grammatical root of his name. Jonson is not only mocking his audience for believing Epicene is a woman, but also for believing that performance can do anything other than hide a stable and fixed reality. We, like Truewit, are shown to be fools for believing in theater.

And once we understand we have been duped, we can retroactively grasp why Dauphine has been opposed to Truewit from the start. ${ }^{34}$ In the first act, Dauphine worries that Clerimont has told Truewit too much about their plots and observes "this frank nature of his is not for secrets" (1.3.5-6). And later when Truewit asks Clerimont and Dauphine to place the Collegiates in the gallery, so they can watch as he humiliates Daw and La Foole, Dauphine remarks, "This is extreme vanity now; thou think'st thou wert undone if every jest thou mak'st were not published" (4.5.237-238). Dauphine isn't (only) worried about Dauphine's vanity or his potential to blab, his anxiety runs deeper. In fact, Truewit demonstrates his humility by giving credit to Clerimont. Truewit's need for an audience isn't vanity; it emerges from his ideas about the

\footnotetext{
${ }^{33}$ See for instance, Ayers, 83; William Slights, Ben Jonson and the Art of Secrecy (Toronto: University of Toronto Press, 1994), 79; J.A. Jackson, "“On forfeit of your selves, think nothing true': Self-Deception in Ben Jonson's Epicoene, ” Early Modern Literary Studies 10, no. 1 (2004):1-28.

${ }^{34}$ Charles A. Carpenter long ago suggested a retroactive reading of the play; he usefully points out that there is no reason to assume that Jonson only wanted his play viewed or read once. The play can be reevaluated after the final reveal. Indeed, as I have been arguing, Jonson himself reevaluated the play after the first performance, hence the second prologue. Carpenter, “Epicoene Minus Its Secret: Surprise as Expectation," Xavier University Studies, 7 (1968):15-22.
} 
authenticity of performance. According to Truewit, secrets and performances without audiences don't create identities; the public performance of identities constitutes authentic identities. In other words, Dauphine is right; Truewit "is not for secret" because secrets presuppose an authentic reality those secrets are hiding. Dauphine's strategy of keeping and then disclosing secrets relies on a belief that a stable and true identity lies underneath the performed fiction of social performance. Dauphine and Truewit can't be on the same team because, while they have the same goal (getting Dauphine his inheritance), they are employing two different techniques that each rely on different notions of performance. Truewit's "frank" nature poses an almost existential threat to Dauphine.

However, this theoretical conflict between Truewit and Dauphine is not that simple. As I suggested above, Jonsonian masques don't disclose identities to reassert a stable identity, they reveal in order to construct. And in fact, this addition through subtraction occurs at the end of Epicene. By uncovering the "true" character of Epicene - "a gentleman's son that I have brought up this half year at my great charges"(5.4.199-200) - most of the characters' identities change: Dauphine moves from poor, disinherited nephew to the rich heir of Morose's fortune; Morose moves from married to unmarried. Daw and La Foole are now seen to be liars in addition to being cowards since they seemed to have lied about having sex with Epicene.

And these changes to their identities are not merely produced by exposing a false performance; they are produced through another performance. When Dauphine promises to get Morose out of his marriage, he makes sure he does it in front of witnesses. "If I quite you not presently and for ever of this cumber, you shall have power instantly, afore all these, to revoke your act" (5.4.181-183, emphasis mine). Here Dauphine is relying on Truewit's techniques: just as Truewit needs to "publish" his japes, Dauphine needs to make public his unveiling of Epicene. 
The change of identity is portrayed not as the negation of a performance, but as another layer of performance.

Similarly, when Morose signs the contract that promises Dauphine his wealth, he declares, "Here, I deliver it thee as my deed. If there be a word in it lacking or writ with false orthography, I protest before - I will not take the advantage” (5.4.195-197). Editors have long wondered who Morose is protesting before. Most early editors assumed that the dash here was a substitute for "God," but Dutton and others have shown that this probably wasn't the case since there would be no reason to fear printing the word "God." ${ }^{35}$ What seems likely here is that Morose is protesting before those watching him sign the document. ${ }^{36}$ In other words, signing the document is not enough, since he can always get out of the contract through an interpretive quibble ("false orthography"). He is calling attention to the theatrical and performative nature of his signing. He is, in effect, performing his own defeat. So while it may seem that Dauphine's final disclosure reasserts an essential and unperformed identity, the plot keeps circling back to the necessity of performance. Even the reveal of a performance is in and of itself another performance.

\footnotetext{
${ }^{35}$ For instance, Robert M. Adams in an early Norton edition of Jonson's Plays (Ben Jonson's Plays and Masques) omits the dash and inserts God. For arguments against the substitution theory, see Dutton's notes to the Revel's edition. Bevington in the 2012 Cambridge edition also suggests the dash is grammatical. Epicene, in The Cambridge Edition of the Works of Ben Jonson, ed. David Bevington (Cambridge: Cambridge University Press, 2012), 3: 503. Ben Jonson's Plays and Masques, ed. Robert M. Adams (New York: Norton, 1979).

${ }^{36}$ Indeed, at other times in the text, a dash indicates a gesture, as when Morose asks his interlocutor to silently bow instead of verbally replying. However, in my own examination of the Newberry's copy of the 1620 quarto edition of Epicene and the 1616 Folio edition, I have found that grammatical dashes were routinely shorter than the dashes used for gestures. The dash after "protest before" was a shorter and therefore probably a grammatical dash. Nevertheless, the above argument does still suggest that Morose wanted an audience. Ben Jonson, Epicoene, or the silent woman, in The workes of Beniamin Ionson (London, 1616); Ben Jonson, Epicoene, or the silent woman A comedie. Acted in the yeare 1609 (London, 1620).
} 
Truewit vs Dauphine Round 2: The Comeback of the Masque

In addition to these caveats to Dauphine's apparent victory over Truewit, Jonson also gives Truewit the last words of the play, and in his big final speech we get an (almost) final reassertion of the authenticity of performed identity. Truewit begins his speech by identifying with the audience and admitting that his uses of performance have been undermined. "Well, Dauphine, you have lurched your friends of the better half of the garland, by concealing this part of the plot! (5.4.220-222). Again, there is a metadramatic pun on "plot." Truewit, like the playhouse audience, didn't know which plot - trick and fictive narrative - he was watching. And "lurched" suggests that Dauphine has stolen credit from Truewit and his "friends" - other characters in the play but also the audience. On a fictive level, Dauphine can take credit for securing his own reputation, and Truewit's attempts to do the same are shown to be ineffectual. But as we have seen, the stakes are much more theoretical and meta. Truewit has also seemingly lost the battle over the efficacy of social performance.

Truewit, however, does not give up that easily. The rest of his speech does not describe the reality that Dauphine has uncovered; instead, he describes the real effects of the fiction that Dauphine had produced. Specifically, he describes how Daw and La Foole's identities are shaped through Dauphine's performance.

Sir Daw and Sir La Foole, you see the gentlewoman that has done you the favours! We are all thankful to you, and so should the womankind here, specially for lying on her, though not with her! You meant so, I am sure? But that we have stuck it upon you today in your own imagined persons, and so lately, this Amazon, the champion of the sex, 
should beat you now thriftily for the common slanders which ladies receive from such cuckoos as you are. You are they that, when no merit or fortune can make you hope to enjoy their bodies, will yet lie with their reputations and make their fame suffer. (5.4.224235).

I quote at length here because Truewit is giving a forceful, if nuanced and subtle, restatement of his initial position. Though he reinforces Dauphine's unmasking of Epicene by forcing Daw and La Foole to look at his "true" identity, he also seems to maintain that they did in fact sleep with the "gentlewoman" (and note, he still refers to Epicene as a woman). He asserts that they lied on her and not with her. This is normally read as they lied about (or "on") sleeping with her (or "lying" with her). But the pun works both ways; he is also saying that they slept on top of Epicene, suggesting a sexual position where they would be the penetrators and Epicene the penetrated - the socially acceptable way of sleeping with a young man. ${ }^{37}$ But while they may have slept with him, they were not lying with him. That is, not telling the "truth with him" since they were not in on the joke. In other words, Epicene was their accidental ingle.

Nevertheless, Truewit will stick them with their own "imagined persons." Whether or not they actually slept with Epicene is beside the point; they will become the identities that they pretended to be - gallants who slept with Morose's male fiancé. And the careful reader will remember that according to Truewit, having a young male lover is part of the accoutrement of a gallant. ${ }^{38}$ Because their fictional (lying) personas have become their authentic identities, they will now have to pay a real, material price - a beating by women. Truewit then is not merely

\footnotetext{
${ }^{37}$ As Mario DiGangi points out, within Epicene this homoerotic sexuality would have been socially sanctioned as long as it was "orderly." Digangi,"Asses and Wits: The Homoerotics of Mastery in Satiric Comedy,” English Literary Renaissance 25 (1995):185-186.

${ }^{38}$ I am referring of course to Truewit's description of Clerimont's gallant behavior in Act 1 , scene I: "What between his mistress abroad and his ingle at home, high fare, soft lodging, fine clothes, and his fiddle ..." (1.1.23-25).
} 
exposing the two for who they "really" are; he is seeking to validate their own lies. Once again, Truewit is attempting to turn a social performance into an authentic identity.

Truewit's final lines, significantly spoken directly to the playhouse audience, further snatches victory from Dauphine's triumph. "Spectators, if you like this comedy, rise cheerfully, and now Morose is gone in, clap your hands" (5.4.248-249). The final lines point back to the generosity of the prologue and reassert the importance of pleasure within a social performance. Truewit, like the first prologue, is encouraging the audience's enjoyment because their pleasure is integral to the success of performed identity. Morose's performed identity as someone who cannot stand noise is cleverly embedded within this standard Renaissance call for applause. ${ }^{39}$

Significantly, this metadramatic appeal to the audience is not done to call attention to the inauthenticity or fictiveness of the performance. Truewit is still playing Truewit - he is not revealing himself to be an actor playing the part of Truewit. And Morose is still Morose, hence Truewit's ironically compassionate advice to the audience - they can now make noise because he has left the stage. He does not do what Dauphine did - uncover the "true" identity of the actors Instead, he doubles down on the performed characteristics of Morose. The audience withholding applause until Morose exits confirms the authenticity of Morose's ailment. Even if Dryden was technically wrong and there was no "real" or extra-dramatic Morose, he was in a sense right since Morose was never shown to be unreal or inauthentic. The real Morose is the dramatic Morose. By the end of the play, he remains a complete, authentically performed identity. And finally, these lines allow Truewit to play one final trick that confirms the authenticity of performance, but this time the trick is on the audience. By asking for the

\footnotetext{
39 Jeremy Lopez notes that "more than any other drama, early modern drama talks about and openly solicits applause." Jeremy Lopez, Theatrical Convention and Audience Response in Early Modern Drama (Cambridge: Cambridge UP, 2003), 33.
} 
audience's applause and asserting that the audience could have a real effect on the fictional performance, the play is not exposing the performance to be inauthentic; it is integrating the real audience into the fictional performance. The audience is no longer (or never was) the object of the performance; they are the subject of the performance, just as masques make the performers both the audience and the performance. This technique, in an odd way, completes the effects of the realistic aspects of the play mentioned above. Just as its realism seeks to break down the distance between the actors and the audience, the final integration of the audience into the performance collapses that distinction completely. Put another way, Truewit's call for applause works like an anti-Brechtian-Verfremdungseffekt. Metadrama is used to draw the audience into an authentic performance instead of being used to make the audience aware of the inauthenticity of reality. In short, instead of making reality a performance, Truewit's trick makes the performance real.

Jonson vs Arabella: Dauphine Wins by Proxy

There is, however, a final reversal - the second prologue — which ultimately confirms Dauphine as the winner. This prologue can be usefully read as an extra-dramatic peripeteia, which reverses Truewit's inter-dramatic victory. While Truewit and Truewit's masque-like faith in the authenticity of performed identity seems to have the last word, the second prologue written after the initial performances ultimately reaffirms Jonsonian hostility to instability and theatrically performed identity. This prologue, more or less, fits perfectly within Jonson's notoriously hostile attitudes towards audiences.

The ends of all who for the scene do write 
Are, or should be, to profit and delight.

And still't hath been the praise of all best times,

So persons were not touched, to tax the crimes.

Then, in this play which we present tonight

And make the object of your ear and sight,

On forfeit of yourselves, think nothing true,

Lest so you make the maker to judge you.

For he knows, poet never credit gained

By writing truths, but things (like truths) well feigned.

If any yet will, with particular sleight

Of application, wrest what he doth write,

And that he meant or him or her will say:

They make a libel which he made a play (1-14).

In this prologue, he berates the audience for reading too much into the play and for identifying real people with the fictional characters on stage. Just as Dauphine exposed the audience to the fiction of his performance, the prologue is reminding the audience of the inauthenticity of the play by asserting a stable reality that exists beneath the performance. Performance is not true but “things (like truths) well feigned.” He is unmasking (or unmasqueing!) his own performance to show that the play is not a constructed reality but a feigned reality.

And we are now in a position to see how the second prologue emerges from the first prologue and the play proper. As previously mentioned, this prologue seems to have been written after Lady Arabella took offense to a passing reference about her in the play. In so doing, she, like the second prologue, is asserting a stable identity (herself) that lies beneath the performance. 
Jonson's second prologue then is not so much rebutting Arabella's claims as confirming them. While he doesn't admit to writing about her, he does assert that he is representing (not constructing) identities, thereby confirming her general reading strategy.

Lady Arabella probably complained on February $8^{\text {th }} 1610$ (though it is unclear when Jonson heard of the complaint), and Dutton convincingly argues that the first performance of the play couldn't have occurred before January $4^{\text {th }}$ of the same year. And according to several critics, his next play, The Alchemist reaffirms Jonson's commitment to the stable, eternal and fixed. ${ }^{40}$ If Dutton is right, then the optimism about performance and generosity towards the audience that I believe is present within Epicene was short lived indeed. On the other hand, in the pages of this journal, Derek B. Alwes has recently argued that The Alchemist can be read (pace Barish and Greene) as a celebration of decentered selves, suggesting that Jonson asks his audience to identify with Face and the other protean performers. ${ }^{41}$ Perhaps, Jonson's optimistic view of performance and theatricality outlived Lady Arabella's last second victory.

\footnotetext{
${ }^{40}$ For a comprehensive summary of these readings, see Derek B. Alwes, "Service as Mastery in The Alchemist," Ben Jonson Journal 17, no.1 (2010) 39-42.

${ }^{41}$ Ibid.
} 